\title{
NVMO-congres 2005
}

\section{Juryrapport}

Voor het NVMO-congres 2005 zijn drie prijzen beschikbaar gesteld. Een prijs is uitgeloofd voor de beste poster, een voor de beste paper/presentatie en een voor de beste wetenschappelijke paper. De prijzen waren, per categorie: een bos bloemen als men nog bij de uitreiking aanwezig was, de uitnodiging om de poster/paper/wetenschappelijke paper tot een artikel te bewerken dat in het Tijdschrift voor Medisch Onderwijs (TMO) gepubliceerd kan worden, en de mogelijkheid om voor $€ 150$ te kiezen uit uitgaven van de uitgeverij Bohn Stafleu van Loghum.

De jury bestond uit mw. dr. Cisca Griffioen (voormalig bestuurslid van het Onderwijsinstituut Geneeskunde AMC-UvA), Joost Hoekstra (student geneeskunde/studentbestuurslid in het Onderwijsinstituut Geneeskunde AMC-UvA en studentbestuurslid in het NVMO-bestuur), dr. Lambert Schuwirth (Universiteit Maastricht en lid van het Wetenschappelijk Comité NVMO-congres 2005) en dr. Jan van Dalen (redactielid van het TMO, Universiteit Maastricht) (voorzitter).

De jury heeft eerst alle abstracts verdeeld, zodat vermeden werd dat iemand een oordeel moest geven over een eigen abstract. De jury lette op: originaliteit, relevantie, het overstijgen van lokaal belang en vorm. In gezamenlijk overleg zijn daarna de beste abstracts van posters, papers en wetenschappelijke papers genomineerd. Tenslotte zijn de presentaties van de genomineerde abstracts bezocht en beoordeeld op inhoud, structuur, presenteerstijl, tijdbewaking en discussie. De genomineerde posters zijn bekeken en beoordeeld op mate van uitnodiging, lay-out, inhoud en boodschap.

De prijs voor de beste poster is gewonnen door M.C.H. Hogenes \& B. Takkenberg (UMC Utrecht) voor de poster Het co-accident: prikken en protocollen. De jury heeft deze prijswinnaar gekozen omdat het abstract en de poster een eenduidige boodschap bevatten, met een goede heldere onderzoeksvraag. Het onderzoek dat beschreven staat, is goed uitgevoerd. Speciaal vermeldenswaardig is het feit dat het hier een onderzoek betrof naar een verschijnsel (prikaccidenten) dat eerder is onderzocht; het huidige onderzoek grijpt daarop voort. Het medium 'poster' is goed gebruikt: niet te veel informatie, een heldere indeling, zeer bescheiden en functioneel gebruik van kleur en goed leesbaar.

De prijs voor de beste paper is gewonnen door K. Hendrickx, B.Y. de Winter, W.A.A. Tjalma, G. Peeraer, D. Avonts \& J.J. Wyndaele (Universiteit Antwerpen) voor de paper Het aanleren van intieme onderzoeken met simulatiepatiënten en het leereffect op de prestaties van de student tijdens de stages. Dit onderzoek werd zeer relevant geacht. Het onderzoek is bovendien zorgvuldig opgezet en uitgevoerd. De presentatie was duidelijk, gestructureerd, binnen de tijd. De presentatrice ging adequaat en zelfverzekerd om met vragen uit het goed publiek.

Voor de beste wetenschappelijke paper is de aanmoedigingsprijs gewonnen door M.A.C.E. van Kats \& L.W.T. Schuwirth voor de paper Invloed van zekerheidsinschatting van studenten bij de beantwoording van verschillende vraagtypes met goed-min-fout scores. Haar abstract en presentatie zijn gekozen vanwege de heldere beschrijving en de goede opzet van het onderzoek. In haar studie is niet een analyse gemaakt van reeds aanwezige gegevens, maar er is daadwerkelijk een experiment opgezet. De presentatie was goed gestructureerd en binnen de beschikbare tijd. De discussie die op de presentatie volgde was levendig, maar dat werd ook in de hand gewerkt doordat het onderwerp zich daartoe goed leende. De beste abstracts zijn aan het einde van deze bijdrage opgenomen, met uitzondering van de abstracts van de prijswinnaars. Deze auteurs hopen hun artikel dit jaar in het TMO te publiceren.

Jan van Dalen

Voorzitter jury NVMO-congres 2005 


\section{Posters}

\section{Praktische problemen bij de imple- mentatie van de Korte Klinische Beoordeling \\ A.B. Bijnen, A.E.R. Arnold, M.L.C. Stikkel, S.J. van Luijk, J.A.A.M. van Diemen- Steenvoorde Medisch Centrum Alkmaar/VUmc}

Probleemstelling: Vanaf 1 januari 2006 wordt de Korte Klinische Beoordeling (KKB) een verplicht onderdeel van het toetsingsprogramma van de vervolgopleidingen. De ervaring hiermee in Nederland is echter gering. Bovendien is maar weinig bekend over de praktische problemen die de implementatie op grote schaal hiervan met zich meebrengt. Velen zijn echter overtuigd van het nuttig rendement van de KKB voor het leerproces van de assistent. Om de kans op succes dan ook zo groot mogelijk te maken, is het van belang dat potentieel belemmerende factoren en factoren die de implementatie bevorderen zichtbaar worden, zodat hiermee rekening kan worden gehouden bij de toepassing van het instrument in de praktijk. Ook de ideeën van het management zijn belangrijk, omdat onderwijs- en toetsprogramma's directe implicaties hebben voor de organisatie van de zorg.

Methode: Teneinde hierin inzicht te krijgen werd eerst een enquête voorgelegd aan 22 medewerkers (11 managers en 11 clinici, waaronder een assistent en een coassistent) van een academisch ziekenhuis met de volgende vragen:

1. Welke positieve effecten verwacht $\mathrm{u}$ van de invoering van de KKB?

2. Welke faktoren zouden de invoering kunnen belemmeren?

3. Hoe kan de invoering van de KKB bevorderd worden?

Op grond hiervan werd een twee uur durende focusgroepbijeenkomst georganiseerd met deelnemers uit een niet-academisch ziekenhuis (3 managers en 5 clinici, waaronder 2 assistenten) met vragen met betrekking tot de motivering van betrokkenen, de kwaliteit van de KKB en de meerwaarde voor de zorg.

Resultaten: Als voornaamste positieve factor kwam naar voren dat de invoering van de $\mathrm{KKB}$ zal leiden tot een directe, gerichte en gestructureerde feedback, die (zelf)reflectie en bewustwording stimuleert en zal bijdragen tot het verbeteren van het praktisch functioneren van de aios, en daarmee de kwaliteit van de zorg. Als obstakels voor de implementatie worden gezien de benodigde tijd, de subjectiviteit van de beoordeling en een mogelijk gebrek aan motivatie bij de opleiders. Invoering en handhaving van de kwaliteit worden bevorderd door het opstellen van duidelijke richtlijnen, het trainen van de beoordelaars in het afnemen van een KKB en het geven van feedback, en het een duidelijke plaats te geven in de organisatie. Er komt geen duidelijk verschil in opvatting tussen de subgroepen naar voren.

Conclusie: Alle groeperingen zijn overtuigd van het nut van de KKB voor de opleiding. Voornaamste knelpunt is de investering in organisatie en tijd, maar deze vertaalt zich ook terug in een toegenomen kwaliteit van de zorg. Implicatie voor de praktijk: De invoering moet adequaat worden voorbereid. Tevoren moet zoveel mogelijk weerstand worden weggenomen door middel van goede informatie, discussie op refereeravonden en andere bijeenkomsten, en professionalisering van de docenten. Zorgvuldigheid bij de introductie en nauwgezette monitoring zijn een voorwaarde om de KKB tot een succesvol en blijvend toetsingsinstrument te maken.

\section{Voelen medische studenten zich op hun gemak bij het aanleren van het lichamelijk onderzoek door het oefenen met elkaar? L.G. van Doorn, G.H.C. van der Heijden, B. Bonke, W.B. de Koning Erasmus MC}

Probleemstelling: Het is gebruikelijk dat studenten geneeskunde het lichamelijk onderzoek (LO) aanleren door te oefenen op elkaar. De indruk bestaat dat ze daar in het algemeen niet veel moeite mee hebben, maar dat het onderzoek van de 'sensitieve gebieden', zoals de liesstreek en de vrouwelijke thorax, soms problemen oplevert. Literatuur hierover is schaars. In Rotterdam, waar actief en passief onderling oefenen van het $\mathrm{LO}$ verplicht is, is nagegaan in welke mate eerstejaarsstudenten zich op hun gemak voelden bij verschillende aspecten van het onderling oefenen en welke factoren daarbij een rol spelen.

Methode: Alle aanwezige studenten (227 우 우 en $\left.114 \sigma^{7} \sigma^{7}\right)$ bij een instroom van 410 van het eerstejaarscohort 2004-2005 vulden in april en mei 2005 aan het begin van een practicum- 
sessie anoniem vragenlijsten in. Vrouwelijke studenten werden tevens bevraagd over het zich (on)gemakkelijk voelen bij het geheel ontbloten van het bovenlichaam voor het ondergaan van het thoraxonderzoek.

Resultaten: Meest frequente religieuze orientaties: 94 protestant, 58 RK, 20 islamitisch, 9 hindoe, 181 diverse overigen of geen religie. Etniciteit: allochtoon $21.1 \%$, autochtoon $78.9 \%$. Uit de voorlopige analyses blijkt dat studenten zich bij het LO in het algemeen in grote meerderheid op hun gemak voelden:

- Uitvoeren/zelfde geslacht

$94.6 \%$

- Ondergaan/zelfde geslacht

$90.8 \%$

- Uitvoeren/andere geslacht

$75.8 \%$

- Ondergaan/andere geslacht

$66.9 \%$

Deze percentages waren over de hele linie beduidend (20-30\%) lager wanneer het specifiek het onderzoek van thorax (우) en liesstreek (우우 en $\sigma^{3} \sigma^{7}$ ) betrof. Ook was dat het geval bij allochtone studenten, bij studenten met islamitische en hindoeïstische achtergronden, en bij studenten met een opvoeding die negatief stond tegenover het tonen van bloot aan anderen dan intimi. Zich gemakkelijk voelen bij het ondergaan van het LO bleek samen te gaan met een als 'goed' ervaren sfeer binnen de studiegroep, tevredenheid over het eigen uiterlijk, de mogelijkheid tot het vergroten van de privacy middels gesloten gordijnen, het gevoel goed voorbereid te zijn op de gang van zaken bij het practicum, de opgebouwde ervaringen in de loop van het studiejaar en een positief ervaren begeleiding door docenten en student-assistenten.

Conclusies: Bij het op elkaar oefenen van het LO door dit zeer pluriforme cohort eerstejaarsstudenten geneeskunde voelde men zich tegen het einde van het studiejaar in meerderheid op zijn gemak. Bij het onderzoek dat de 'sensitieve gebieden' betreft voelde men zich (vooral de vrouwelijke studenten) echter niet zelden ongemakkelijk. Gezien de gerapporteerde positieve bijdrage van de opgebouwde ervaring in de loop van het studiejaar lijkt het interessant om dit cohort de komende jaren verder te volgen. Behoudens het waar mogelijk verder optimaliseren van de hierboven aangegeven positieve factoren, is er vooralsnog geen reden om de opzet van het practicum ingrijpend te wijzigen.

\section{Ontwikkeling van een Computer Ondersteund Onderwijs classificatie met behulp van een klankbordgroep S. Eggermont, P.M. Bloemendaal, A.J.M. de Man, M.J. Quaak, P.F. de Vries Robbé Leids Universitair Medisch Centrum}

Probleemstelling: In januari 2005 is het Surf-samenwerkingsproject 'Study Coach And Learning Environment' (SCALE) van start gegaan tussen het LUMC, Erasmus MC, UMC St Radboud, en het UMC Utrecht. Het SCALEproject beoogt onder andere het centraal aanbieden van computer ondersteund onderwijs (COO)-materiaal ten behoeve van medische onderwijsinstellingen. Om COO-materiaal te kunnen vinden, is het nodig dat er een classificatie voor dit type onderwijs wordt ontwikkeld die in diverse instellingen gebruikt kan worden.

Methode: Om de classificatie goed af te stemmen op de verschillende instellingen, is een klankbordgroep in het leven geroepen. Deze groep is samengesteld uit 11 medewerkers van verschillende universiteiten en bedrijven die betrokken zijn bij de ontwikkeling van COO. Tijdens een brainstormsessie werd geïnventariseerd op welke kenmerken men COO-materiaal wil kunnen selecteren. Deze inventarisatie leverde een gevarieerde lijst op met 46 systeemeigenschappen en classificatiekenmerken, waarin is aangegeven welke eigenschappen vereist, wenselijk of ongewenst zijn. Aangezien te verwachten valt dat verschillende gebruikers op grond van verschillende criteria COO-materiaal willen kunnen selecteren, werd dit per gebruikersgroep aangegeven: studenten, docenten, COO-ontwikkelaars en beleidsmakers.

Resultaat: De lijst is door 5 klankbordgroepleden en 5 projectleden ingevuld, een respons van $50 \%$. Na eliminatie van de synoniemen en ongewenste eigenschappen zijn deze als volgt te groeperen:

- Beschrijvende kenmerken en suggesties voor vocabulaires voor het classificeren van $\mathrm{COO}$ materiaal (bv. MeSH voor medische onderwerpen).

- Administratieve metadata van COO-materiaal.

- Aanpassingen aan de onderwijsomgeving (bd. koppeling met Blackboard ${ }^{\circledR}$ ).

- Systeemeigenschappen van de studiecoach en de zoekmachine (bv. zoeken als in Google). 
Voor de verschillende gebruikersgroepen is een grote variatie geconstateerd tussen vereiste, gewenste en ongewenste eigenschappen.

Discussie: De beschrijvende kenmerken hebben de COO-classificatie bepaald. Hierin werden 5 onafhankelijke groepen onderscheiden: COOtypering, techniek, curriculum informatie, medische inhoud en onderwijskunde, die als onafhankelijke takken in de classificatie zijn opgenomen. De technische aanpassingen zijn of worden gerealiseerd. De systeemeigenschappen van de studiecoach en de zoekmachine zijn verwerkt in het functioneel ontwerp, waarin de eigenschappen per gebruikersgroep worden vastgelegd.

Conclusie: De klankbordgroep heeft de opzet voor een classificatie geleverd over verschillende assen, waarin het COO-materiaal wordt ondergebracht. De werking van de studiecoach en het zoekmechanisme wordt bepaald door deze classificatie en de metadata van het COO-materiaal. Naar verwachting zal dit de acceptatie van de studiecoach vergroten en de onderlinge uitwisseling van COO-materiaal tussen alle medische instellingen vergemakkelijken. Doordat rekening wordt gehouden met verschillende gebruikersgroepen, kan een gerichter studieadvies aan studenten worden gegeven en kunnen zoekopdrachten van studenten, docenten en beleidsmakers beter worden beantwoord. De tussenresultaten worden getoond tijdens de presentatie.

\section{Zeven jaar Onderwijskwalificaties (BKO) bij diergeneeskunde: een re- trospectief onderzoek naar de relatie tussen omvang BKO-portfolio en aandacht voor zelfreflectie \\ S.T.T. Hubers, P. van Beukelen \\ Faculteit der Diergeneeskunde, Universiteit Utrecht}

Probleemstelling: Docentprofessionalisering is sinds 1997 structureel onderdeel van het personeelsbeleid van de Universiteit Utrecht: al het wetenschappelijke personeel dient een Basiskwalificatie Onderwijs (BKO) te behalen. Het BKO-traject kenmerkt zich door: 'leren op de werkvloer', feedback van tutor en studenten, en didactische trainingen. De Faculteit der Diergeneeskunde heeft BKO-criteria opgesteld betreffende kwantiteit, variëteit en kwaliteit van de onderwijstaken. Beoordeling van een BKO-traject vindt plaats middels een portfolio. 'Zelfreflectie' beschrijft wat is geleerd van eigen onderwijservaringen en feedback daarop, en kent 4 stappen: terugblikken, concluderen, aanpassen, uitproberen. Zelfreflectie is daarmee een essentieel onderdeel van het portfolio. Vanaf 2000 worden aan de Faculteit der Diergeneeskunde BKO-trajecten afgerond. De probleemstelling van het onderzoek luidt: is er een ontwikkeling in de hoeveelheid zelfreflectie waar te nemen in de tijd, op welke onderwijsvormen en -fasen wordt het meest gereflecteerd en verschillen de disciplinegroepen van elkaar? Methode: Alle BKO-trajecten, afgerond tussen 1 januari 2000 en 1 mei 2005, zijn geïnventariseerd op disciplinegroep, tutor en achtergrond van de docent (dierenarts/geen dierenarts). De portfolio's zijn gescoord op omvang en mate van zelfreflectie. De zelfreflectie is gescoord per BKO-criterium (o.a. onderwijs voorbereiden, onderwijsuitvoering, toetsing) op de 4 stappen van de reflectiecyclus.

Resultaten: In de aangegeven periode hebben 55 docenten het BKO-traject succesvol afgerond: 21 uit de prekliniek, 18 uit de parakliniek en 16 uit de kliniek. De hoeveelheid zelfreflectie in portfolio's is over de afgelopen 5 jaar niet significant toegenomen. De hoeveelheid reflectie in portfolio's hangt wel samen met het departement waarbinnen de docent werkzaam is en daarmee wellicht met de tutor. Ondanks dat het belang van het hoorcollege als onderwijsvorm de afgelopen jaren sterk is afgenomen, wordt hier door BKO-kandidaten het meest op gereflecteerd. Er wordt weinig gereflecteerd op het toetsingsproces. De meeste reflecties hebben betrekking op de daadwerkelijke uitvoering van het onderwijs. Conclusie/implicaties voor de praktijk: Het instellen van een BKO heeft geleid tot een structurele aanpak van docentprofessionalisering binnen de Faculteit der Diergeneeskunde. Een verdere verbetering van de BKO-trajecten, inclusief de aandacht voor zelfreflectie, kan mogelijk worden gerealiseerd door instelling van een structureel overleg van tutoren uit alle disciplinegroepen.

\section{Elektronische onderwijsevaluatie door studenten: sterke en zwakke kanten \\ B. Morlion, R. Rubens, A. Derese, $K$. Coolsaet, S. Wauters \\ Universiteit Gent}

Probleemstelling: Sinds 1993 worden aan de Universiteit Gent studentenbevragingen georganiseerd als middel in de interne kwaliteitszorg. 
Deze evaluaties gebeurden aanvankelijk op papier, later werd ook gestart met elektronisch evalueren. Dit elektronisch evaIueren bood voordelen in verwerkingsnelheid, maar leidde tot een daling van de participatie. In 2004 werd een nieuw evaluatiesysteem ingevoerd dat tegemoet komt aan de knelpunten van de vorige evaluatiesystemen.

Opzet: Het programma beoogt een vlotte(re) afname en verwerking, het verkorten van de kwaliteitscyclus, het verminderen van de administratieve workload, een uniformere beoordeling van de docenten, een (grotere) gebruiksvriendelijkheid en (daardoor) een voldoende participatie van de studenten.

Methode: Elke student logt in met een wachtwoord dat in het begin van het academiejaar wordt toegekend en krijgt hiermee toegang tot de evaluatie van die programmaonderdelen die hij (of zij) gedurende het voorbije academiejaar gevolgd heeft. Hij kan slechts één keer antwoorden voor elk programmaonderdeel, maar zijn antwoorden blijven verder anoniem. Per programmaonderdeel kan het onderdeel zelf en de 4 belangrijkste docenten apart worden beoordeeld. Voor elke vraag zijn er 5 antwoordmogelijkheden (van zeer goed tot zeer slecht). Een neutrale of positieve waardering hoeft niet te worden gemotiveerd (maar het mag), een negatief oordeel leidt tot het automatisch doorklikken naar een meer gedetailleerde bevraging en een open antwoordmogelijkheid. Over de resultaten wordt automatisch een rapport gestuurd naar de docenten, die veertien dagen de tijd krijgen om hierop te reageren. Hierna vindt een (subcommissie-)bespreking plaats met de onderwijsdirecteur, de beleidsmedewerker kwaliteitszorg, de directeur van het Centrum voor Onderwijsontwikkeling, de voorzitter van de opleidingscommissie en twee studentenvertegenwoordigers. Hierna wordt een oordeel geformuleerd voor het onderwijsdossier. Indien nodig wordt de docent gecontacteerd door de voorzitter van de opleidingscommissie of de onderwijsdirecteur.

Ervaringen: Uit de gegenereerde rapporten, de reacties van de lesgevers en de studenten, en de besprekingen in de subcommissie blijkt dat:

1. Klassikale afname in de pc-klas leidt tot hogere participaties dan evalueren in 'eigen tijd' (79\% vs. $38 \%)$.

2. De docenten krijgen (te) weinig positieve oordelen te lezen over hun onderwijsprestatie, omdat uitsluitend negatieve oordelen toegelicht dienen te worden.
3. Studenten zich te weinig realiseren dat hun commentaar (weliswaar anoniem, maar) ongefilterd naar de docenten gaat.

4. De actuele behandeling in de subcommissies vooral ondermaatse onderwijsprestaties detecteert.

Excellente onderwijsinzet en -prestaties worden op deze manier moeilijker gedetecteerd, en dragen hierdoor onvoldoende bij aan beslissingen inzake bevordering.

Implicatie voor de praktijk: Volgend academiejaar worden méér klassikale bevragingen beoogd. Studenten zullen bewust worden gemaakt dat zij feedback formuleren t.a.v. de docent. Positief waarderen van excellente onderwijsprestaties dient gebruik te maken van andere kanalen dan (enkel) studentenbevragingen.

\section{Papers}

\section{Het opleidingsklimaat van acade- mische en perifere ziekenhuizen: hoe artsassistenten verloskunde \& gynaecologie en kindergeneeskunde dit klimaat op hun afdeling ervaren \\ K. Boor, M. Raphaël, C.P.M. van der Vleuten, A. Scherpbier, R. van Diemen- Steenvoorde, F. Scheele Sint Lucas Andreas Ziekenhuis}

Probleemstelling: Het opleidingsklimaat beinvloedt, los van alle onderwijsvernieuwingen, wat artsassistenten leren en hoe tevreden zij zijn over hun opleiding. In deze studie wordt gekeken naar verschillen in het opleidingsklimaat tussen twee specialismen (kindergeneeskunde en verloskunde \& gynaecologie) en naar verschillen tussen academische en perifere ziekenhuizen.

Methode: Op het jaarlijks congres voor artsassistenten kindergeneeskunde en tijdens de jaarlijkse voortgangstoets van artsassistenten verloskunde \& gynaecologie, zijn vragenlijsten over het opleidingsklimaat verspreid. Een gevalideerde vragenlijst, de 'Postgraduate Hospital Educational Environment Measure' (PHEEM), is afkomstig uit Dundee en met toestemming van de auteurs vertaald naar het Nederlands. De vragenlijst bestaat uit 40 items. Er zijn drie subschalen te onderscheiden:

1. Perceptie van onderwijs (bv.: 'De klinische docenten hebben goede onderwijsvaardigheden'). 
2. Perceptie van sociale steun (bv.: 'Er is een goede begeleiding van arts-assistenten die onvoldoende functioneren').

3. Perceptie van autonomie (bv:: 'Ik heb een passend niveau van verantwoordelijkheid in dit artsassistentschap').

Elk item kan gescoord worden op een 5-puntsschaal, waarbij 1 gelijk staat aan 'helemaal oneens' en 5 aan 'helemaal eens'. Berekeningen zijn uitgevoerd met gemiddelde scores. Verschillen zijn gemeten met behulp van de Mann-Whitney test. De 'effect size' (bepaling van praktische relevantie) is bepaald met Cohen's $d$.

Resultaten: 109 artsassistenten kindergeneeskunde (respons 93\%) en 249 artsassistenten verloskunde \& gynaecologie (respons 100\%) hebben de PHEEM ingevuld. In verband met onvolledig ingevulde lijsten zijn 10 kindergeneeskundevragenlijsten en 9 verloskunde \& gynaecologievragenlijsten uitgesloten van analyse (n-totaal 339).

Verloskunde\&gynaecologievskindergeneeskunde: De verschillen tussen de twee specialismen zijn na correctie voor type ziekenhuis niet significant.

Academie vs periferie: Van de 99 ingevulde lijsten door artsassistenten kindergeneeskunde zijn 57 artsassistenten afkomstig uit een academisch en 42 uit een perifeer ziekenhuis. Artsassistenten gynaecologie vulden 240 lijsten in: 110 zijn afkomstig uit de academie, 130 uit de periferie. Assistenten afkomstig uit een perifeer ziekenhuis ervaren een positiever opleidingsklimaat dan hun academische collegae. De Cohen's d ligt bij de kindergeneeskunde tussen de 0.5 en 0.8 , wat duidt op een middelgroot effect; de effect size bij gynaecologie ligt boven de 0.8 , wat een groot effect representeert (zie tabel 1).

Conclusie: Deze studie onder Nederlandse artsassistenten verloskunde \& gynaecologie en artsassistenten kindergeneeskunde toont aan dat de gemiddelde score op de PHEEM in een perifeer ziekenhuis significant hoger is dan in een academisch ziekenhuis. Nader (kwalitatief) onderzoek om gevonden verschillen tussen universitaire en niet-universitaire centra te verklaren is geïndiceerd.

\section{Een onderwijsstage voor semiartsen als voorbereiding op een studenten- onderwijskwalificatie: win-win?$$
\text { Th.J. ten Cate }
$$$$
\text { UMC Utrecht }
$$

Inleiding: Per september 2004 is als keuzemogelijkheid een zesweekse onderwijsstage ingevoerd voor studenten (semiartsen) in het nieuwe zesde jaar van het Utrechtse CRU'99curriculum. Deze stage sluit aan bij de behoefte om studenten ervaring te laten opdoen met de

Tabel 1 Gemiddelde scores op de PHEEM voor assistenten kindergeneeskunde en gynaecologie in academische en perifere centra.

\begin{tabular}{|c|c|c|c|c|}
\hline & $\begin{array}{l}\text { Totaalscore } \\
\text { (SD) }\end{array}$ & $\begin{array}{l}\text { Onderwijs } \\
\text { (SD) }\end{array}$ & $\begin{array}{l}\text { Sociale steun } \\
\text { (SD) }\end{array}$ & $\begin{array}{l}\text { Autonomie } \\
\text { (SD) }\end{array}$ \\
\hline \multicolumn{5}{|l|}{$\begin{array}{l}\text { Kindergeneeskunde } \\
(n=99)\end{array}$} \\
\hline $\begin{array}{l}\text { Academisch ziekenhuis } \\
(\mathrm{n}=57)\end{array}$ & $3.45^{*}(0.48)$ & $3.48^{*}(0.55)$ & $3.46^{*}(0.52)$ & $3.49^{*}(0.51)$ \\
\hline $\begin{array}{l}\text { Perifeer ziekenhuis } \\
(\mathrm{n}=42)\end{array}$ & $3.79^{*}(0.45)$ & $3.79^{*}(0.56)$ & $3.83^{*}(0.46)$ & $3.84^{*}(0.54)$ \\
\hline $\begin{array}{l}\text { Cohen's d } \\
\text { (mate van effect) }\end{array}$ & $\begin{array}{c}0.72 \\
\text { (middelgroot) }\end{array}$ & $\begin{array}{c}0.55 \\
\text { (middelgroot) }\end{array}$ & $\begin{array}{c}0.76 \\
\text { (middelgroot) }\end{array}$ & $\begin{array}{c}0.67 \\
\text { (middelgroot) }\end{array}$ \\
\hline \multicolumn{5}{|l|}{$\begin{array}{l}\text { Verloskunde \& Gynaecologie } \\
(n=240)\end{array}$} \\
\hline $\begin{array}{l}\text { Academisch ziekenhuis } \\
(\mathrm{n}=110)\end{array}$ & $3.53^{* *}(0.43)$ & $3.47^{* *}(0.54)$ & $3.55^{* *}(0.47)$ & $3.57^{* *}(0.49)$ \\
\hline $\begin{array}{l}\text { Perifeer ziekenhuis } \\
(n=130)\end{array}$ & $3.96^{* *}(0.45)$ & $3.91^{* *}(0.54)$ & $3.98^{* *}(0.46)$ & $3.98^{* *}(0.50)$ \\
\hline $\begin{array}{l}\text { Cohen's d } \\
\text { (mate van effect) }\end{array}$ & 0.98 (groot) & 0.81 (groot) & 0.93 (groot) & 0.82 (groot) \\
\hline
\end{tabular}

${ }^{*} \mathrm{p}<0.005$.

${ }^{* *} p<0.001$. 
uitvoering van onderwijs. Dat past in het model van de algemene competenties van de medisch specialist in de toekomst. De student die de stage succesvol afsluit, ontvangt een optionele Studenten-onderwijskwalificatie(StOK). Destudent wordt ingedeeld bij een studieonderdeel dat zelf in het verleden is gevolgd. Dit paper geeft een beschrijving van deze onderwijsvorm en van de eerste ervaringen in de praktijk.

Methode: Tijdens iedere zesweekse module van het schakeljaar volgen gemiddeld vier studenten een onderwijsstage. De stage bevat voor de student de volgende verplichtingen:

- Observatie van onderwijs door een of meer docenten.

- 20 uur zelfstandig contactonderwijs verzorgen (30 uur indien de student een StOK wenst).

- Tenminste driemaal tijdens de onderwijsuitvoering geobserveerd en beoordeeld worden.

- Uitvoeren van een onderwijskundig project in overleg met de coördinator van het studieonderdeel waar de student bij is ingedeeld.

- Leveren van feedback over het studieonderdeel aan de coördinator.

- Uitwerken van een medisch-onderwijskundig verdiepingsonderwerp en schrijven van een paper hierover.

- Bestuderen van de bundel Learning \& Teaching in Medicine - een serie uit de British Medical Journal - en afleggen van een toets hierover.

- Opstellen van toetsvragen en op hun kwaliteit beoordeeld worden.

De studenten ontvangen twee typen begeleiding: vanuit het studieonderdeel (door de coördinator of een andere begeleidende docent) en vanuit het onderwijsinstituut.

Ervaringen tot nu toe: De onderwijsstage verloopt succesvol. Per mei 2005 hebben 14 studenten de stage met succes afgerond (13 inclusief StOK). Coördinatoren van studieonderdelen zijn na afloop tot dusver onveranderlijk positief over de onderwijsstagestudenten. De semiartsen beschouwen de stage als "zwaar, maar wel te doen". De zwaarte blijkt vooral afhankelijk van de inhoud van het studieonderdeel waarbij men is ingedeeld. Soms vergt de voorbereiding van de werkgroepen zeer veel energie, die overigens meestal achteraf als de moeite waard wordt beschouwd. Ook de jongerejaarsstudenten waarderen in het algemeen de werkgroepen die door studenten worden verzorgd.

Conclusies: De stage lijkt in meerdere opzichten succesvol te zijn. De semiartsen doen onderwijs- ervaring op, zij verdiepen zich in een relevant medisch studieonderdeel en leren daar (weer) van, de feedback op het studieonderdeel lijkt te leiden tot verbeteringen in het onderwijsprogramma en de inspanning voor de begeleiding van de studenten bij het studieonderdeel wordt gecompenseerd door het feit dat de stagiair ook onderwijs overneemt. De Studenten-onderwijskwalificatie is een gewaardeerde toevoeging aan het c.v. Gestreefd wordt naar verdere ontwikkeling door meer gerichte trainingen en meer gezamenlijke besprekingen van medisch-onderwijskundige thema's tijdens de stage.

\section{Etnische diversiteit, studievoortgang en studie-ervaringen van vierdejaars- studenten aan het Erasmus MC Rotterdam \\ V.J. Selleger, B. Bonke, Y.A.M. Leeman \\ Erasmus MC Rotterdam/Universiteit van Amsterdam}

Probleemstelling: Een etnisch gemengde studentenpopulatie biedt studenten de gelegenheid interculturele communicatie te oefenen en kan bijdragen aan de ontwikkeling van culturele competenties. Daarnaast bestaat echter het risico van spanningen tussen studenten of ongelijke behandeling door opleiders. In 2001 werd voor het eerst in Nederland de etniciteit van een cohort geneeskundestudenten in kaart gebracht. De cohort eerstejaarsstudenten in Rotterdam telde $8 \%(\mathrm{n}=23)$ westerse en $18 \%$ $(\mathrm{n}=50)$ niet-westerse allochtonen, met 30 verschillende landen van herkomst. In 2003 werden, als tweede stap in dit onderzoek, 17 studenten geïnterviewd over hun studieervaringen. Zij gaven aan dat de gemengde populatie tot dan toe weinig problemen, maar ook weinig winst had opgeleverd. Als derde stap werd begin 2005 het gehele vierde studiejaar geënquêteerd met als onderzoeksvragen:

1. Heeft de etnische achtergrond van studenten uit de cohort 2001 invloed op hun studievoortgang?

2. Hebben vierdejaarsstudenten discriminatie of ongelijke kansen ervaren?

3. Leren studenten met verschillende achtergronden door onderling contact tijdens de studie?

Methode: Een anonieme enquête, tijdens verplicht kleinschalig onderwijs. Door een code konden de enquêtes van 2001 en 2005 aan elkaar worden gekoppeld, met waarborg voor 
anonimiteit.

Resultaten: Van de 211 vierdejaarsstudenten vulden 195 (92\%) de enquête in, man-vrouwverhouding $60 / 135,7 \%(n=13)$ westers allochtoon en $17 \%(n=33)$ niet-westers allochtoon. Er was geen significant verschil in man-vrouwverhouding tussen etnische groepen. Van de 277 respondenten in 2001 werden er nu 180 aangetroffen in het vierde studiejaar: $48 \%$ van de mannen was vertraagd of afgevallen, $27 \%$ van de vrouwen $\left(\chi^{2}: p<0,005\right), 52 \%$ van de westerse allochtonen, $42 \%$ van de niet-westerse en $31 \%$ van de autochtonen (verschillen tussen etnische groepen niet significant). Slechts $4 \%$ van alle respondenten $(n=7$, van wie 3 niet-westers allochtoon) vond dat hun studie werd bemoeilijkt door hun achtergrond; $12 \%(\mathrm{n}=23$, van wie 9 niet-westers allochtoon) meldde zich minstens eenmaal gediscrimineerd te hebben gevoeld, meestal door opleiders $(\mathrm{n}=18)$, zelden door medestudenten $(n=4)$. De meest genoemde grond voor discriminatie was sekse $(n=6)$, gevolgd door etniciteit of ras $(n=4)$. Een meerderheid $(61 \%)$ van de respondenten beschouwde een gemengde studentenpopulatie als een voordeel voor hun eigen studie; $65 \%$ vond dat studenten leren van elkaars cultuur en religie. Toch hadden 62 studenten (van wie 59 autochtoon) geen enkele studievriend met een andere etnische/ culturele achtergrond dan zijzelf.

Conclusie: In de cohort 2001 werd, ruim drie jaar later, geen relatie tussen etniciteit en studievoortgang aangetoond. Enerzijds waardeerde de meerderheid van alle vierdejaarsstudenten de gemengde studentenpopulatie, anderzijds ervoeren sommige studenten discriminatie en mengden autochtone studenten slechter met allochtonen dan andersom. Een gemengde studentenpopulatie is op zichzelf geen garantie dat studenten goede ervaringen opdoen in interculturele communicatie.

\section{Doelstellingen getoetst: is een taxo- nomietabel een bruikbaar instrument om opleidingsdoelstellingen te analy- seren? \\ I. Vandenreyt, M. Maelstaf, $M$. Vandersteen$$
\text { Universiteit Hasselt, Campus Diepenbeek }
$$

Probleemstelling: Uit semigestructureerde interviews met de blokcoördinatoren van de opleiding geneeskunde en uit discussies tijdens een tweedaagse herbronning over 'doelstellin- gen en studeerbaarheid' en 'toetsing' bleek dat veel docenten vragen hebben over de betekenis en de juiste formulering van doelstellingen en de hieraan gekoppelde leeractiviteiten en toetsen. Kan een instrument ontwikkeld worden om na te gaan of de doelstellingen correct zijn geformuleerd en de leeractiviteiten en toetsen congruent zijn met de doelstellingen?

Methode: In samenwerking met de Open Universiteit Nederland (OUNL) werd een procedure ontwikkeld voor het analyseren, correct formuleren en classificeren van doelstellingen naar kennisdimensie en cognitieve procesdimensie, gebaseerd op de tweedimensionale taxonomietabel van Anderson en Krathwohl. De algemene doelstellingen van de opleiding en de doelstellingen van alle opleidingsonderdelen van de bacheloropleiding werden volgens deze procedure geanalyseerd. 23\% van de doelstellingen werd dubbel beoordeeld. De betrokken coördinatoren kregen feedback over de resultaten van dit onderzoek tijdens een curriculumraad in het voorjaar 2005. Op basis van deze feedback moesten 21 blokcoördinatoren reflecteren op de analyse en de classificatie.

Resultaten: In totaal was 80\% van de doelstellingen onnauwkeurig of onvolledig geformuleerd. Een voorstel tot correcte formulering werd gedaan. $15 \%$ van de originele doelstellingen werd behouden, 6\% werd geschrapt. Een aantal leeractiviteiten en toetsopdrachten bleek met geen enkele van de geformuleerde doelstellingen overeen te komen: zij werden vertaald naar een nieuwe doelstelling. Vier blokcoördinatoren reageerden en stelden kleine wijzigingen voor. De overige docenten gingen akkoord met de voorgestelde aanpassingen. De doelstellingen werden geclassificeerd naar kennisdimensie en cognitieve procesdimensie: in het eerste bachelorjaar ligt de nadruk op het begrijpen van conceptuele kennis. Metacognitieve kennis en hogere cognitieve niveaus worden meer zichtbaar in de volgende jaren.

Conclusie: Dit onderzoek zal uitwijzen of de ontwikkelde procedure een bruikbaar instrument is voor de docent om doelstellingen te analyseren, correcter te formuleren en te classificeren naar kennisdimensie en cognitieve procesdimensie. Op basis van hun feedback zal mogelijk verdere bijsturing van het instrument plaatsvinden. In het vervolgonderzoek worden de leeractiviteiten en de toetsvragen in dezelfde taxonomietabel geplaatst. Classificatie van de drie bronnen (doelstellingen, leeractiviteiten en toetsvragen) maakt congruentie en incongru- 
entie tussen doelen, leeractiviteiten en toetsvragen zichtbaar. De blokcoördinator beslist of de leeractiviteiten en de toetsvragen voldoende zijn afgestemd op de doelstellingen en of er aanpassingen nodig zijn.

\section{Wetenschappelijke paper}

\section{Motieven van artsen voor het inzetten van physician assistants \\ M.J.H. Bruurs, G.T.W.J. van den Brink, F.J.M. Holweg, R.S.G. Holdrinet Hogeschool van Arnhem en Nijmegen}

Probleemstelling: De hogeschool van Arnhem en Nijmegen (HAN) is in samenwerking met het UMC St Radboud in 2003 gestart met de Masteropleiding Physician Assistant (MPA). In 2003 zijn 13 studenten en in 2004 zijn 26 studenten gestart uit Zuid en Oost Nederland. Voor de ontwikkeling van de opleiding heeft de HAN een subsidie gekregen van het Ministerie van Volksgezondheid, Welzijn en Sport om het nieuwe beroep physician assistant alsmede de opleiding te ontwikkelen. Het ministerie heeft de HAN nadrukkelijk verzocht tevens een onderzoek te doen naar de effecten van de inzet van deze nieuwe professionals in de Nederlandse gezondheidszorg. Middels een beschrijvend onderzoek wordt inzicht gegeven in:

1. De motieven van artsen om een physician assistant te gaan opleiden.

2. De bevorderende en belemmerende factoren, die worden ervaren bij de invoering van dit nieuwe beroep binnen de verschillende instellingen.
Methode: Semigestructureerde interviews bij mentoren (medisch specialisten, $\mathrm{n}=31$ ) van 39 studenten die 2003 en 2004 gestart zijn met de opleiding.

Resultaten: De respons bedroeg 90\%. De mentoren geven de volgende motieven aan voor het inzetten van een physician assistant:

- Het bevorderen van de continuïteit van zorg.

- Hogere productiviteit.

- Het vervullen van taken die voorheen agnio's en/of artsassistenten vervulden, maar waarvoor moeilijk artsen te vinden zijn.

- Het mogelijk maken dat de de medisch specialist zich meer richt op meer complexe taken.

Ten aanzien van de belemmerende factoren worden genoemd:

- Onduidelijkheid ten aanzien van de financiële kaders en wet- en regelgeving.

- Onduidelijkheid ten aanzien van de positionering van het beroep.

Ten aanzien van de bevorderende factoren worden genoemd:

- Ondersteuning vanuit de organisatie.

- Enthousiasme van de student PA in spé.

Evaluatie/conclusie/implicatie voor de praktijk: De verwachtingen ten aanzien van dit nieuwe beroep zijn hoog gespannen. Door het expliciteren van de verwachtingen is de basis gelegd voor de latere effectevaluatie. 